\title{
50 YEARS OF SOCIOLOGY IN HUNGARY. REPORT ON THE JOINT ANNIVERSARY CONFERENCE OF THE HUNGARIAN SOCIOLOGICAL ASSOCIATION AND THE INSTITUTE FOR SOCIOLOGY OF THE CENTRE FOR SOCIAL SCIENCES OF THE HUNGARIAN ACADEMY ${ }^{1}$
}

\author{
ZSUZSANNA GÉRING ${ }^{2}-$ GÁBOR KIRÁLY ${ }^{3}-$ VERONIKA PAKSI ${ }^{4}$
}

The annual conference for Hungarian sociologists in 2013 was an exceptional event for both those working in Hungary and those who are active abroad. The Institute for Sociology of the Centre for Social Sciences of the Hungarian Academy of Sciences (IS CSS HAS), established by András Hegedüs, celebrated its 50th anniversary. This offered the opportunity for the Hungarian Sociological Association (HSA) and the IS CSS HAS to organize the annual conference together. Since both organizations play pivotal roles in the field of sociology and sociological research, their cooperation alone made the conference special. Furthermore, the venue for the conference was the IS CSS HAS building and the Jacobin Hall at the Buda Castle district, contributing to the ceremonial atmosphere of the event.

As the official communique of the conference emphasized, one of the most important aims of the conference was to include those people who substantially contributed to the Hungarian sociology in the 'early days', thereby shaping

1 This report was carried out under a research program with funding from the Hungarian Scientific Research Fund (OTKA 104707). Head of Research: Beata Nagy, CSc (Associate professor, Corvinus University Budapest)

2 Research fellow, Budapest Business School; e-mail: gering.zsuzsannamargit@gkz.bgf.hu

3 Associate professor, Budapest Business School; Senior lecturer, Corvinus University Budapest. E-mail:kiraly.gabor@pszfb.bgf.hu,gabor.kiraly@uni-corvinus.hu

4 Research Assistant, Institute for Sociology of the Centre for Social Sciences of the Hungarian Academy; PhD student, Institute of Sociology and Social Policy, Corvinus University Budapest. E-mail: paksi.veronika@tk.mta.hu 
the paths, perspectives and methodologies of successive decades. It was also an opportunity to remember and reflect on those outstanding research projects which are still providing inspiration for research activities today, either as foundations to build upon or as reference points for critical reflection and debate. In this fashion, the conference also provided the opportunity to consider former achievements and for professional self-reflection.

The program was intended not only to foster debate and dialogue about the history of Hungarian sociology but also to promote scientific discussions about recent research activities. As a result, the program offered three different modes of attendance and contribution. First of all, the round table discussions offered the opportunity for participants to meet and get acquainted with the founding mothers and fathers of Hungarian sociology and with their 'professional philosophies', respectively. Secondly, various sections were designed to give an overview of the research activities of the past decades concerning the critical assessment of different schools of thought, perspectives and methodological approaches. Finally, at the workshops the younger generation of sociologists could present novel approaches and methodological experiments, thereby reflecting both the recent and the notso-recent history of Hungarian sociology.

Generally speaking, the first day of the conference was a day of remembrance and 'nostalgia'. After welcome speeches delivered by György Csepeli (president, HAS) and Béla Janky (director, IS CSS HAS), Iván Szelényi gave a plenary lecture about the socio-technics and critical social research of Hungarian sociology between 1963 and 1968. Miklós Szántó responded to Szelenyi's speech by presenting a paper entitled 'The era before sociology' ("Előidők"). Those present at the discussions, led by widelyacclaimed experts as Zsuzsa Ferge, Elemér Hankiss, Losonczi Ágnes, Miklós Szántó and Iván Szelényi among others, gained a unique insight into what it meant to be a sociologist in the early days.

There were six roundtables that focused on significant, ubiquitous and comprehensive issues in Hungarian sociology. The topics were as follows: questions concerning the teaching of sociology, the institutionalization of sociology, the issue of playing the role of intermediary between East and West, the relationship between sociology and politics, the question of 'who is a gypsy?' and the issue of new approaches in social critique. The participants of the roundtables were prominent actors from Hungarian social sciences. For example, in the 'The question of teaching sociology' roundtable, the heads of Hungarian higher education establishments that teach sociology evaluated their positions and shared their experiences with others. Through the discussion it became clear that there are significant differences among these 
schools in terms of their structural embeddedness, the number of teachers and students and their educational tasks. In spite of the different interests of the schools, the participants agreed to continue the dialogue.

As far as the five workshops are concerned, 50 people took part, either as presenters of papers or discussants. These workshops represented alternative dilemmas and methodologies in social research which can be witnessed in the Hungarian sociological research community. Moreover, there was also diversity in how these workshops were organized. Some of them included both presentations and discussions, others focused more on the debates about the current situation of a particular branch of sociology. There was also an 'experiment' with the world café format which encouraged 'shopping around' to get acquainted with different participatory research projects and methods. Thematically speaking, there were methodological (including methods such as social network analysis and participatory research) and topic-based (family, social structure, critical theory or recent social history) workshops. 'The family in the $21^{\text {st }}$ century' workshop focused on the issue of whether the Hungarian family at the beginning of the $21^{\text {st }}$ century has new characteristics compared to the end of the $20^{\text {th }}$ century. The speakers proposed new directions for research, such as parental identities, family planning and constitutions of families. Furthermore, a special project was also represented: namely, the 'Voices of the 20th Century Archive and Research Group' which gathers and preserves the audio (and audiovisual) heritage of Hungarian sociology. This particular workshop focused on the previous 40 years of lifestyle research. The individual research projects, which had been deeply embedded in the given environment of the age, clearly indicated the characteristics, position of and opportunities for Hungarian sociology.

As for the sections, there were 13, with 59 papers and 75 contributors. These sections were related to broad topics such as politics (political cleavages and socialization), urban development (urban sociology and policy), methodological issues (sociological methodology in general and stratification in particular), religion, family and interdisciplinary research (interdisciplinary, gender studies, ecological changes, science and technology studies). The 'Social and Political Ruptures' section showed the positions of parties, voters and political ideologies in different segments of the societal sphere. The main goal of the 'Science and Technology Studies' section was to introduce the research activities of social scientists who focus on science, technology and innovation. The dilemma was whether the economic (e.g. modularization) and social (e.g. online representation of the self, online reciprocity) parameters that are related to new technologies can be considered new phenomena or not. The 'Ecological Changes and Social Flexibility' 
section aimed to show the social, economic and political obstacles that hinder the changes needed for the sustainable operability of societies. The 'Family' section showed the pluralization of Hungarian families, and reflected on the most significant social problems that affect families. Last but not least, young researchers participating in the 'Stratification Model 2.0' section attempted to rebuild an earlier stratification model.

The conference was quite eventful and offered further events with different genres. Béla Janky opened the András Hegedüs Room at IS CSS HAS. Michael Bernhard, Professor (University of Florida) held a plenary presentation with the title of 'The Wages of Extrication: Civil Society Strength at Regime Termination and Inequality in Postcommunist Eurasia'. A documentary film: 'Grandfathers and Revolutions' by Péter Hegedüs - the grandson of András Hegedüs, the founder of the IS CSS HAS - was shown. The conference accommodated an exhibition of selected drawings of children connected to Judit H. Sas' research of the '70s. Last but not least, a jubilee cake was cut at the end of the reception held on the evening of the first day.

Although there are many differences in opinion between sociologists in Hungary, this occasion showed that these differences could be dealt with and put aside for such a shared event. 